\title{
Analysis of Xi Jinping's Peasant Education Thought
}

\author{
Wen Zheng ${ }^{1}$ \\ ${ }^{1}$ Yunnan University of TCM \\ Kunming Yunnan 650500, China \\ Email:zhengwen07@126.com
}

\author{
Yuanlin $\mathrm{Hu}^{2}$ \\ ${ }^{2}$ Faculty of Management and Economics, \\ Kunming University of Science and Technology \\ Kunming Yunnan 650093, China \\ Email: 494674978@qq.com
}

\begin{abstract}
The aim of this study is to systematically analyze and introduce $\mathrm{Xi}$ Jinping's thoughts on peasant education. By means of systematic study of Xi Jinping's speech series, the paper summarizes the peasant education thoughts contained in them. And the results show that Xi's thoughts on peasant education include the following points: thoughts on the starting point of the farmer education; thoughts on the leadership of the party organization in the farmer education; strategic thoughts on the construction of spiritual civilization on peasant education; thoughts on the scientific and cultural knowledge education of farmers; the combination of farmer education and precise poverty alleviation; thoughts on the farmer education and safeguarding social fairness and justice; thoughts on the forms and methods of farmer education. The research results indicate that Xi Jinping inherited and developed the Marxist thought of peasant education, which has practical guiding significance for farmers in poverty-stricken areas.
\end{abstract}

Keywords-Xi Jinping; Farmer Education Thought; Expatiates

\section{INTRODUCTION}

By combining the universal truth of Marxism-Leninism with China's concrete reality, Xi Jinping has put forward a set of unique principles, policies, contents, forms and methods of education for Chinese peasants. The formation of the correct theoretical principles and experience summary of the Communist Party of China on peasant education under the new situation.it is an in-depth consideration of the major theoretical and practical issues concerning "peasant education". Understanding and mastering $\mathrm{Xi}$ 's thoughts on peasant education is of great practical significance to strengthening peasant education, improving the quality of peasants in an allround way, building a moderately prosperous society and realizing the Chinese dream of great rejuvenation of the Chinese nation.

\section{DISCUSSION ON THE STARTING POINT OF FARMERS 'EDUCATION}

According to the actual situation of "agriculture, rural areas and farmers" under the conditions of the socialist market economy, Xi summed up several basic starting points for peasant education: First, it is necessary to cultivate the allround development of morality, intelligence, physical beauty and laborers who serve socialist construction. What to train and how to train people are the starting point and destination of all educational work. Xi stressed that education should "strive to train the builders and successors of the socialist cause who have developed comprehensively in morality, intelligence, physical integrity and beauty"[1]. Second, people. Adhering to the principle of peasantry education is one of the fine traditions of the party. Only from the standpoint of the people can we fully understand the spiritual essence of peasantry education of $\mathrm{Xi}$ Jinping, which is the value orientation of the people's supremacy. In a series of speeches, Xi Jinping made it clear that "The people's hearts are the greatest politics." "To uphold the people's nature, we must take the realization, maintenance and development of the fundamental interests of the overwhelming majority of the people as the starting point and goal, and put people first and first." Third, science and education to rejuvenate the country. Xi Jinping inherited and developed the strategic thought of rejuvenating the country through science, education and education established at the 16th National Congress of the Party, emphasizing the important position and role of education in realizing the "two centenary goals" and the Chinese dream of great rejuvenation of the Chinese nation. He pointed out that science and technology must be based on the education of farmers to improve the scientific and cultural quality of farmers. For poor areas, it is important to emphasize the significance of science and technology education for economic development and to deal with the relationship between science and technology education and economic development [2]. 


\section{The Thought OF Putting Party ORganization AND LEADERSHIP FIRST IN PEASANT EDUCATION}

Party management of rural work is a tradition of our Party and a major principle that should be adhered to. Peasant education can't be separated from the leadership of the Party. First of all, the Party should have a clear guiding ideology for the management of peasant education. Xi Jinping pointed out that rural Party organizations should lead the masses of peasants to create material and spiritual civilization and take the road of common poverty and prosperity. This is the main theme of all Party organizations 'work. Party organizations must be built into a strong core that leads the peasant masses in their struggle to achieve the Party's line and their immediate interests, so that the broad masses of peasants can draw consensus from practice: "to get out of poverty and become rich, there must be a good branch [3]" Secondly, the Party should strengthen the self-construction of the Party organizations in the management of peasant education. $\mathrm{Xi}$ Jinping stressed that Party members in poor areas must seriously study Marxism-Leninism's basic theory and the Party's principles and policies, learning scientific and cultural knowledge, learning business management knowledge, and be good at exploring the rules of the operation of the commodity economy, so as to become the leaders of socialist commodity production. Only then can they truly lead the people to get rid of poverty and become rich [4]. Thirdly, the Party should improve its working methods in the management of peasant education. At the rural reform forum in Xiaogang Village, Fengyang, Anhui Province. In 2016, Xi Jinping pointed out that the tradition of Party management of rural work must not be lost. Party committees at all levels should strengthen their leadership over the work of the "three peasants and peasants", Leading cadres at all levels should go to the countryside and visit farmers 'homes more often. They should understand farmers' demands and expectations, resolve rural social conflicts, and sincerely help farmers solve practical problems in production and life. We need to build Party organizations at the grassroots level in rural areas into the core of strong leadership in implementing Party policies, leading peasants to become rich, closely connecting with the masses, and maintaining rural stability

\section{XI JINPING'S THOUGHT ON RAISING THE CONSTRUCTION OF SPIRITUAL CiVILIZATION TO THE HigH LEVEL BY THE PEASANT EDUCATION STRATEGY}

$\mathrm{Xi}$ stressed that we should "raise the level of strategic understanding of spiritual civilization" and "correct the position of spiritual civilization from the height of strategic principles. To truly achieve the construction of two civilizations together, "we must be willing to spend some money and invest some money in the construction of spiritual civilization, and actually do a few things for the people to have a long spirit and a long ambition[5]" During the period when Xi Jinping was in politics in Zhengding, in order to change the dirty and chaotic phenomena in Zhengding cities and villages, he vigorously promoted the "Spiritual Civilization and Politeness Month" and emphasized that "the two civilizations" must be caught together. He proposed that we should take the communist ideal and belief education as the core, catch the style of the party and the people, catch the county town and the countryside, and catch the typical belt, focusing on the management of dirty, chaotic, and poor, and pay close attention to environmental purification, greening, and beautification. Rectify public order, expand the position of cultural activities, let the wind of civilization blow into each family courtyard, and let the flowers of civilization spread out throughout the land. Since the 18th National Congress, he has not only paid attention to the improvement of farmers 'cultural quality, but also paid attention to the education of ethics and morality, the improvement of backward social customs, and advocated the development concept of building a new spiritual homeland with moral beauty. Because the beauty of the countryside is not beautiful, civilization is not civilized, it is related to the happiness index of the masses, and it is related to the formation of a well-to-do society in an allround way. A good village spirit can bring people together, concentrate their hearts and bring them together in spirit. It has become an indispensable spiritual support for economic development and provides a vital guarantee for social progress.

\section{XI JINPING'S THOUGHT ON EDUCATING FARMERS IN SCIENCE AND TECHNOLOGY}

$\mathrm{Xi}$ Jinping attached great importance to the scientific and cultural knowledge education of farmers and put forward the educational ideology of "science and technology to promote agriculture." Xi Jinping pointed out early that the development of our agriculture must take science and technology as a basic policy, rely closely on scientific and technological progress, increase the yield per unit area of planting and aquaculture, and form a high yield, low consumption, high quality and efficient agricultural production system. Xi Jinping once joined the northern Shaanxi countryside as an educated youth, the work and life experience in the countryside has enabled Xi Jinping to have a profound understanding of the education of farmers in science, technology and culture. Xi Jinping recalled: "When I joined the team in Liangjiahe Village, Yanchuan County, Northern Shaanxi Province in 1968, it was only a science and technology activity that was carried out in the village. However, I had tasted the promotion of scientific and technological progress. "Xi Jinping promptly discovered and promoted the Nanping experience of agricultural science and technology commissioners in Fujian provincial leadership positions, and stationed in rural areas by selecting professionals with higher scientific and technological qualifications but serving as special commissioners. The experience of providing multi-layered scientific and technical services such as demonstration, training, guidance and counselling to local farmers was successfully transplanted to Zhejiang and other provinces. Xi stressed that science and technology is the key to poverty eradication and prosperity, and that the scientific and cultural quality of farmers should be continuously improved in the process of advancing scientific and technological progress. We will establish and improve a network of science and technology extension services at the fourth level in rural areas, and employ a group of peasant technicians to enrich the rural technical team. Extruding funds, vigorously training practical technical teams in rural areas, and through agricultural colleges and universities, training a group of peasant technicians with secondary school diplomas to cultivate the backbone of 
agricultural skills that are "kept and used" for rural areas, creating a new generation of farmers.

\section{Xi JinPING's Thought ON COMBINING PEASANT EDUCATION WITH PRECISION POVERTY ALLEVIATION}

$\mathrm{Xi}$ Jinping paid great attention to the work of poverty alleviation and development, paying special attention to the role of education in poverty alleviation. He has repeatedly proposed to rely on education to solve the problem of peasant poverty, and has proposed poverty alleviation strategies such as "helping the poor first", "helping the poor must help the wise", and "precisely aiding the poor". Xi Jinping emphasized that "poverty alleviation must first be supported and the 'poverty consciousness' must be diluted ideologically." Say nothing but poverty everywhere. It is entirely possible for poor areas to 'fly first' in certain areas by their own efforts, policies, strengths and advantages. To make up for the disadvantages brought about by poverty, "poverty alleviation must help wisdom, prevent the intergenerational transmission of poverty," and "education is an important way to block the intergenerational transmission of poverty." On the path of targeted poverty alleviation, Xi advocated "developing education and lifting poverty out of a batch". First, by strengthening compulsory education for farmers' children, $\mathrm{Xi}$ Jinping prevented the transmission of poverty from generation to generation. $\mathrm{Xi}$ attached great importance to education in poor areas, paying particular attention to the growth of the next generation, and made the development of education an important way out of poverty. On December 29 and 30, 2012, when Xi Jinping visited the work of poverty alleviation and development in Fuping County, Hebei Province, he emphasized that the next generation of education should be done well, especially the growth of the next generation in poor mountainous areas, and that children should not lose on the starting line. During the visit to Xiangxi Tujia and Miao Autonomous Prefecture from November 3rd to 5th, 2013, it was said that rural compulsory education should be effectively implemented so that the next generation of rural people can master more knowledge and skills. On November 26, 2013, during a discussion with the leading comrades in charge of Heze City and counties, it was emphasized that if you are no longer poor, you can't be poor. If you are no longer poor, you must ensure that compulsory education is well done and that children from poor families can receive good education. On January 24, 2017, when Xi Jinping visited Zhangjiakou City, Hebei Province, he pointed out that it is necessary to take the development of education and poverty alleviation as the basic plan to ensure that children of poor people can receive good basic education. The second is to carry out accurate poverty alleviation through vocational and technical education for farmers. During his tenure as secretary of the Fuzhou Municipal Party Committee, facing the reality of backward education in rural areas in Eastern Fujian, he pointed out that he should attach great importance to the development of vocational and technical education in poor areas and continuously strengthening the stamina of poverty eradication. in particular, he emphasized that vocational and technical education should be closely combined with the economic and social development needs of the eastern Fujian Province and the needs of farmers to get out of poverty and become rich, including strategic training for rural surplus labor and knowledge youth in rural areas; Vocational and technical education can not only be carried out on the "blackboard", we must pay attention to practice, to teach students practical skills and so on. These unpretentious, practical and easy to understand words are a summary of Comrade Xi Jinping's experience of tireless practical exploration of the problems of peasant education, and they embody the position, views and methods of solving the problems of Marxist analysis. It also reflects the pragmatic style of seeking truth and strong people's feelings.

\section{PEASANT EDUCATION AND THE MAINTENANCE OF SOCIAL EQUITY AND JUSTICE}

The pursuit of equity in education and the equal right to education for all are the values and goals of human society. The main problems to be solved in basic education in China are fairness and quality. When Xi Jinping visited the Bayi School in Beijing in September 2016, he stressed that educational equity is an important foundation for social equity. We must continue to promote the development of education and bring more and more equitable benefits to all people, and promote social equity and justice through education and equity. We must optimize the allocation of educational resources and gradually narrow the regional, urban-rural, and inter-school gaps. Since the 18th National Congress, he has paid special attention to the inequity of China's educational resources in the old revolutionary areas, ethnic minority areas, remote areas and poor areas. During the inspection of the Beijing Normal University, it was clearly pointed out: "The education gap must be strengthened in the western regions, rural areas, old and young areas, and poor areas [6]" When he went to Shaanxi to visit and sympathize with the masses of cadres, he emphasized: "The old revolutionary areas and poor areas must still grasp the roots of development or pay attention to education. Do not let children lose on the starting line. We must pay attention to education and pay attention to basic education, especially basic education in old areas. Financial funds must be tilted toward this aspect. " Under the guidance of Xi Jinping's education ideology, compulsory education, vocational and technical education, education for all and lifelong education in rural areas have been carried out extensively, enabling farmers to enjoy better and more equitable education and gain the ability to develop themselves and benefit society, live a happy life with dignity.

\section{XI JINPING'S DISCUSSION ON THE FORMS AND METHODS OF PEASANT EDUCATION}

The form and method of peasant education in a certain period is a big problem that affects the effectiveness of peasant education. After a long period of investigation and study, Xi Jinping has adopted a more flexible and diverse way of educating farmers in accordance with the reality of their lives. As early as when he was at the local level, Xi Jinping had a profound understanding of how to proceed from reality and improve the working methods of peasant education. "We can't $t$ still be accustomed to the ideological and political working methods of 'speaking on the stage and listening under the stage' in the past, but should go deep into every household. To do the ideological work to the heart of every farmer; we can't wait for 
reports and give instructions, but should take the initiative to identify problems and help farmers solve various practical difficulties. We can't still rely on any administrative force to control the peasants. Instead, we should make the peasants firmly unite around ourselves by doing practical things for the peasants and close relations between the Party and the masses [8]". These "three can't and three should" are precisely Xi Jinping's ideas for innovating peasant education in a flexible and diverse manner, starting from the actual situation in rural China. After serving as General Secretary of the Party, Xi Jinping has a great vision of how to give full play to the role of peasant education in transforming science and technology into real productive forces on the road to growing agriculture through science and education. He advocates the development of large-scale agriculture and efficient ecological agriculture, and "the core is to solve the problems of good people." In terms of training and positioning, it is necessary to "cultivate and create new types of peasants, professional peasants, and new types of agricultural operations"; In terms of training targets, "the training of young farmers is included in the National training plan for practical talents, attracting young people to farm, and ensuring that there are successors to agriculture"; From here, we can clearly realize that $\mathrm{Xi}$ Jinping has put forward a new task and effective approach for peasant education, which will provide a solid manpower foundation and guarantee for the modernization of agriculture and the sustained and healthy development of agriculture.

\section{REFERENCES}

[1] Xijinping. To fully implement the Party's education policy and strive to improve our basic education. Xinhua News Agency, 2014-09-09(1).

[2] Xi Jinping's "Three Help" Poverty Alleviation Theory: Poverty Alleviation First Support to Poverty Alleviation Must Support Wisdom. International Online (Beijing), 2015-09-11 15:44:17.

[3] Xi Jinping talks about building a good rural party organization. Tianjin Daily, 2015-09-18(1).

[4] Xijinping. China must strengthen agriculture, China must be beautiful in the United States, and China must be rich in the rich farmers. People's Daily, 2016-2017 -29(1).

[5] Xijinping. The deep love of knowledge. Hebei People's Publishing House, December 1, 2015.

[6] When Xi Jinping visited Beijing Normal University, he called on teachers across the country to be good teachers who are satisfied with the party and the people. People's Daily, 2014-09-10(1).

[7] On the eve of the Spring Festival, Xi Jinping went to Shaanxi to visit and sympathize with the masses of cadres and people to send new spring blessings to the people of the whole country. People's Daily, 2015-0217(1).

[8] Xijinping. Get out of poverty. Fujian People's Publishing House, 2014.08 . 